Mateja Brozović*

Sanja Sever Mališ**

Ana Novak ${ }^{* * *}$
JEL Classification M41

Original scientific paper

https://doi.org/10.32910/ep.70.3.7

\title{
THE CONSISTENCY AND COMPLEXITY OF ACCOUNTING TERMINOLOGY IN CROATIAN HIGHER EDUCATION SYSTEM
}

Usually the most important role of language is to facilitate communication, which often proves challenging if the used terminology is inconsistent, complex or not understandable. These issues may especially affect specific language that is characteristic for a certain profession, particularly when the members of the profession communicate the message to the outsiders. Literature review suggests that the accounting terminology may sometimes be perceived as complex or incomprehensible, due to multiple changes and variations of accounting terms. Since there is a lack of research in the field of higher education, a research was conducted with the aim of analyzing accounting terminology used in the higher education institutions in Croatia. Both secondary and primary data were used in the analysis. The secondary data included accounting courses curricula of a sample of higher education institutions in Croatia, which were analyzed in order to explore the consistency of accounting terminology. In addition, the research was supplemented by collecting primary data using questionnaire on the attitudes of students

${ }^{*}$ Dr. sc. M. Brozović, Teaching and Research Assistant, Faculty of Economics and Business, University of Zagreb (E-mail: mbrozovic@efzg.hr).

${ }^{* *}$ Dr. sc. S. Sever Mališ, Associate Professor, Faculty of Economics and Business, University of Zagreb (E-mail: ssever@efzg.hr).

*** Dr. sc. A. Novak, Assistant Professor, Faculty of Economics and Business, University of Zagreb (E-mail: anovak@efzg.hr).

The paper was received on October 2nd, 2018. It was accepted for publication on January 8th, 2019. 
about the complexity of accounting terminology. The analysis of accounting terms used in accounting courses curricula led to a conclusion that the analyzed courses, in most cases, are not harmonized regarding the terminology used. However, these results were expected from the previous research, that showed that the same applies for the Croatian regulatory accounting framework, which is why it was concluded that using different synonyms for the same accounting concepts may be beneficial for students. As for the students' attitudes towards accounting terminology, the students who participated in the research mostly agree that the accounting courses often use different synonyms for the same concept. Although they perceive this as confusing, they are also aware that using multiple synonyms during courses for the same accounting concepts is useful because it serves as a preparation for practice. On the other hand, they mostly disagree with the statement that the accounting terminology is too complex and incomprehensible, which has proved to be influenced by the students' characteristics, such as the type of study program enrolled, year of study, number of accounting courses attended, secondary school type and working experience. This research complements previous research conducted in Croatia in other areas where the accounting terminology is present, such as the legislation or in practice among business professionals, which is its main scientific contribution As for the practical implications, results of the research may serve as an indicator to educators and legislators in their future actions, since the potential problem of inconsistency and complexity of accounting terminology in courses' curricula are a direct consequence of inconsistency and complexity of terminology in accounting legislative.

Keywords: accounting terminology, higher education institutions, accounting courses curricula, harmonization, synonyms.

\section{Introduction}

Although language can be attributed many roles, the main role of language is to facilitate communication among members of society. In the context of communication, a successfully transmitted message to another party means that both parties in the communication process understand the sent message in the same way. To ensure that sent messages are not ambiguous, the language must be clear and accurate. However, according to Sirbu (2015), "language is an actor that both shapes, and is shaped by the social community in which it plays a significant role", meaning that there are several factors that have to be taken into account when analyzing language or meaning of words, such as the socio-cultural environment, eco- 
nomic and historical influences, technological progress etc. This is why Norberg and Johansson (2013) state that the knowledge of the whole setting or frame in which a certain word occurs is required in order to acquire the full understanding of the word.

An additional factor that can potentially create communication problems is the fact that language changes over time. Apart from the changed meaning of specific words, new words may enter a language and sometimes replace other words (Evans, 2010). According to Blank (1999), conditions that may lead to language innovation include: the need to verbalize new concepts, sociocultural change, cognitive motivations, speaker's attempts to reduce complexity or irregularity in the lexicon, as well as the psychological causes. When a new concept emerges, which is frequent both in professional language and in general everyday language, there are several ways of finding a suitable word for the concept. These ways include semantic change, where an existing word changes meaning or adopts additional meaning, borrowing words from another language or creating a new word (Evans, 2010). Such changes usually occur gradually and can sometimes result in contradictory meanings of words which exist at the same time. Such inconsistencies can create difficulties in communication and fulfilling the main role of language. However, language should be perceived as a dynamic concept that evolves and adapts over time, which is why the challenges that come with it are usually inevitable.

Such relations between words and the meaning of words are studied within the part of the linguistics that is called lexicology. Basic relations between words include hypernymy/hyponymy, synonymy, antonymy and homonymy. The very existence of a lot of different synonyms and homonyms in a language, as words that share meaning with other words and words that have the same spelling and pronunciation but different meanings, make the language more complex and may cause communication problems. That is why there are opponents of differences in terminology. For example, Silhan (1978) states that "each segment of the profession needs to minimize unnecessary differences in terminology", especially focusing on the academic segment that often overlooks the effects of divergent terminology. On the other hand, the existence of different synonyms can be viewed in the context of enriching the language, meaning they have a positive and negative side.

\section{Previous research on accounting terminology}

Every profession is specific and therefore develops its own professional terminology, as a structured set of concepts and associated terms within a given sub- 
ject area. Terminology can be viewed as a medium for knowledge transfer, which is why a harmonized, agreed and easily accessible terminology is a prerequisite for precise and unambiguous professional and scientific communication. This both applies to a single and interlanguage communication (Hrvatski terminološki portal, 2018). Although a specialized terminology is crucial for the effective communication between the members of a particular profession, it also serves its purpose in communicating with people outside the profession.

An example of a specialized terminology that is to some extent important for the general public is the accounting terminology, due to the concepts of corporate governance, financial reporting and information asymmetry. According to Evans (2010), "accounting is a language for specific purposes", which is highly specialized and serves a variety of purposes. Some of the topics and issues regarding the accounting terminology that have been studied in the previous research include: the use of synonyms and variations in terminology, inconsistent uses of terms, frequent changes in the accounting terminology, translation issues in international communication, and misunderstanding outside the profession.

Silhan (1978) stated that "the emergence of different terminology in the accounting literature is a recurring problem". Understanding issues are causes by the use of synonyms, as well as the discrepancy between terms and what they refer to. There is a practice of using synonyms in the laws related to accounting in Croatia (Mamić Sačer, Pavić and Žager, 2018). Synonyms may create a problem in understanding when people are not familiar with them and do not recognize them as synonyms. Moreover, their understanding also depends on who people perceive them. Many words have such a complex meaning that not even professionals within the same profession and country have the same conceptual understanding of them (Norberg and Johansson, 2013). An example is the concept of the "true and fair view" as opposed to "presents fairly", which are both concepts used in financial reporting. Although these concepts are supposed to be synonyms according to the regulators and standard setters (Williams, 2005), there is a possibility that this is not perceived in the same way from the standpoint of preparers and users of financial statements. In case these terms have different meanings for different participants in financial accounting, they may contribute to an expectation gap (Kirk, 2001), defined as the difference between the expectations of financial reports users and actual responsibilities of the accounting profession when preparing financial statements (Porter, 1996). Understanding issues are also evident in case of the terms referring to the likelihood that are used in the accounting standards, such as "probable", "reasonably possible" and "possible". According to Lee and Ling (2016), "difficulty in applying these terms might result in lack of comparable financial statements if accounting professionals do not interpret the terms consistently, both within a jurisdiction, and across jurisdictions". Their research findings indicate that there is a significant variation in a way that Australian ac- 
counting professionals interpret terms that refer to likelihood, which is why they suggest that standard setters should consider additional guidance so that the intent of the terms of likelihood in the accounting standards is clear. Additionally, Dickins at al. (2016) have shown that minor differences in terminology can result in unexpected disparities in the extent of the audit tests performed when reaching the conclusion regarding the company's ability to continue as a going concern. Differences in wording were related to the use of terms "substantial doubt" and "significant doubt", where the tests proved that the use of different terms related to the going concern criteria results in different practice outcomes. All these cases call for special caution when using accounting terminology, as misunderstanding or misrepresentation can lead to significant consequences.

In addition to the complexity and variations of accounting terms, the additional issue is the changes in used terms. Changes in accounting terminology are usually introduced by issuers of accounting or auditing standards and legislators. For example, an important change in accounting terminology was introduced when the International Accounting Standards Board presented new titles of financial statements, renaming "balance sheet" to "statement of financial position" in order to better reflect the function of the statement (Evans, 2010). However, there is always a certain time delay in the adoption of such new terms in practice, and sometimes even resistance, especially regarding such widely adopted terms such as the "balance sheet". This means that multiple understanding issues may arise during the phase of transition to the new terms.

The translation issue emerged when the need for unifying accounting standards on the international level was recognized. Although the need to standardize accounting world-wide is undisputable in order to achieve international comparability of financial reporting, research has shown that the linguistic and cultural aspects in accounting communication cannot be ignored. Norberg and Johansson (2013) analyzed the translation of the American English term "income" in bilingual English/Swedish and Swedish/English dictionaries to highlight the risk of miscommunication involved in the translation process. According to their results, non-technical uses of terms are often confused with technical uses, and the "information presented in bilingual technical dictionaries may be both incorrect and misleading" (Evans, 2010). Evans (2004) pointed out that the full equivalence in translation between languages is rare, which means that the risk of misunderstanding increases when the technical terms are translated into another language, especially when different legal or accounting traditions clash. Therefore, despite the processes of globalization, standardization and harmonization, accounting and accounting terminology is still under the influence of language barriers.

Accounting terminology may in particular be incomprehensible to persons outside the accounting profession, which especially applies to the users of financial 
statements who usually do not have accounting education or experience. These issues are not a recent phenomenon. A review of academic and professional writing on accounting communication conducted by Stolle (1973) revealed that the major concern has been with the quality of the communication between accountants and users of financial statements. Apart from the lack of knowledge of specific accounting terms, the misunderstanding is also caused by the fact that certain terms may have different definitions in everyday usage as opposed to the professional accounting terminology. Even in the cases where both professional accountants and non-accounting practitioners agree on the definition, there is still a possibility that the term might be interpreted differently by different groups of persons (Evans, 2010). Although the process of financial reporting is aimed at reducing the information asymmetry, as a common problem for a majority of stakeholders that have a certain interest in a company, accounting communication issues are certainly a challenge in achieving this goal.

The majority of the previous research on accounting terminology was related to the issues encountered in accounting practice. However, all these challenges can equally affect the education system. It should be taken into account that the education system, especially when it comes to higher education, and the accounting practice are mutually interrelated, primarily due to the cooperation of educational institutions with accounting practitioners and the fact that students later translate their knowledge into practice. Since this area in Croatia has not been sufficiently researched, the need for carrying out research on the consistency and complexity of accounting terminology in higher education institutions in Croatia has been recognized. Research results will complement the results of the research already conducted in other areas where the accounting terminology is present: Croatian legislation related to accounting (Mamić Sačer, Pavić and Žager, 2018) and among business professionals in a form of managers and accountants (Mamić Sačer, Dečman and Rep, 2018).

\section{Consistency of accounting terminology in curricula of higher education institutions in Croatia}

In order to analyze the consistency of accounting terminology used in higher education, a research was conducted on a sample of higher education institutions in Croatia. According to the Agency for Science and Higher Education (cro. Agencija za znanost $i$ visoko obrazovanje - AZVO), the total number of certified institutions that provide study programs within the area of social sciences and field of economy is 41 , which refers to 12 university faculties, and 29 polytech- 
nics and colleges. The main criteria for selecting institutions in the sample was the availability of courses curricula on the institutional website. The sample consisted of 12 higher education institutions, out of which 6 university faculties, and 6 polytechnics and colleges. A total of 132 curricula of accounting courses were analyzed. The research was limited to undergraduate and graduate study programs (integrated undergraduate and graduate university study, undergraduate university study, graduate university study, undergraduate professional study and specialist graduate professional study). University specialist postgraduate study programs and university postgraduate (doctoral) study programs were excluded from the research, since there is a lack of available information about the active university specialist postgraduate study programs, while the university postgraduate (doctoral) study programs usually have very few accounting courses. Out of the total number of certified study programs in the field of economy that are registered at AZVO, 25.60\% of them are university specialist postgraduate study programs and only $5.31 \%$ are university postgraduate (doctoral) study programs. The main aim of the research was to calculate the occurrence frequency of selected accounting terms in cases were there are multiple synonyms in order to reach conclusions if there are dominant terms that are used. These terms were selected on primarily on the basis of scanning the analyzed curricula and extracting the terms that are the most frequent. The list of terms that were identified in that way was further supplemented with the terms that were analyzed within the Croatian accounting regulatory framework by Mamić Sačer, Pavić and Žager (2018).

The main research results are summarized in Table 1. Selected accounting terms are systematized into five groups according to their field: financial statements, elements of financial statements, general accounting terms, managerial accounting and auditing. Along with the Croatian terms are the equivalent English terms. It should be noted that in certain cases where there are multiple synonyms, there is only one appropriate English translation, which is especially present with terms that have versions created by adapting English terms, as well as versions that are more in the spirit of Croatian language. Percentages calculated in the table indicate the percentage of courses (out of total 132) in which the specific accounting term is mentioned in the curriculum. 
Table 1.

\section{THE OCCURRENCE FREQUENCY OF SELECTED ACCOUNTING TERMS IN THE ANALYZED CURRICULA}

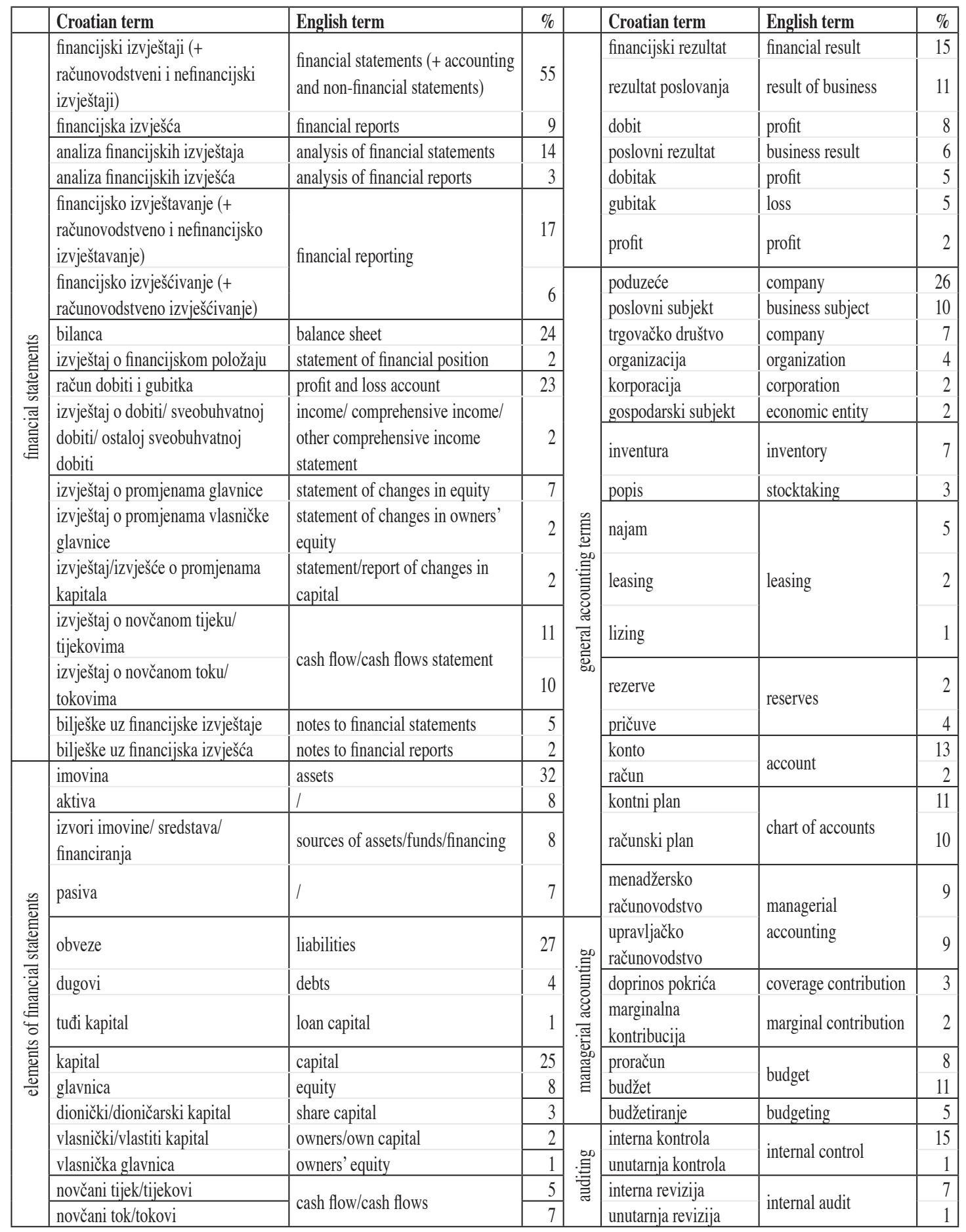

Source: calculated by the authors. 
Research results have shown that the term financial statements prevails over the term financial reports, which also applies to similar derived terms (e.g. financial reporting and analysis of financial statements). Regarding the titles of financial statements, accounting courses are harmonized when it comes to the balance sheet and the profit and loss account. These terms dominate in relation to the alternative terms statement of financial position and income statement, although these are the new titles introduced by the International Accounting Standards Board (IASB). This is a proof that there is always a certain time lag in the adoption of terms that are imposed on a regulatory basis, especially when these new terms are supposed to replace previous well-known terms that have been used for decades. On the other hand, analyzed accounting courses are not uniform regarding the titles of other financial statements. There are two equally represented titles for the cash flow statement (cro. izvještaj o novčanom tijeku/tijekovima and cro. izvještaj o novčanom toku/tokovima), which are not distinct terms in English. A similar situation applies for the statement of changes in equity (which is a dominant term), alternatively named statement of changes in owners' equity or statement of changes in capital. It is interested to notice that this is not valid when it comes to the individual elements of financial statements, where the term capital prevails over the term equity.

There is evident influence of foreign languages on accounting terms in Croatian language. In addition to the native terms that are in the spirit of Croatian language, synonyms that emerged as a literal translation from a foreign language are also often used. In some cases, these borrowed terms got so domesticated that they became dominant (e.g. konto vs. račun, budžet vs. proračun, interne kontrole vs. unutarnje kontrole, inventura vs. popis). However, there are also opposite cases, where the native terms prevail (e.g. najam vs. leasing, pričuve vs. rezerve).

The main conclusion derived from analyzing the content of accounting courses curricula in higher education in Croatia is that there is no consistency regarding the accounting terms used, except for some exceptions such as the balance sheet. These results are expected, since the research conducted by Mamić Sačer, Pavić and Žager (2018) showed that the same applies for the Croatian regulatory accounting framework. Different outcomes in the higher educational system cannot be expected until accounting terminology is harmonized at the legislative level. On the contrary, using different synonyms for the same accounting concepts may be beneficial for students, since it prepares them for what they can expect in practice. 


\section{Attitudes of students on the complexity of accounting terminology in Croatia}

Apart from the potential inconsistency problem, terminology can generally be characterized as complex, especially if it refers to a specific professional field such as accounting. This is why the research was supplemented by examining the attitudes of students about the complexity of accounting terminology. This second part of the research was conducted within one university faculty that was also included in the sample of higher education institutions whose accounting courses curricula were analyzed. The main tool for collecting data was the questionnaire, which consisted of four parts: 1) general questions about respondents, 2) rating statements related to accounting terminology in Croatia, 3) choosing the preferred terms from a list of synonyms, and 4) understanding and connecting synonyms. The answers were collected electronically during June 2018 and the questionnaire was distributed to a total of 636 students.

The total number of respondents that answered all the questions in the first and the second part of the questionnaire is 180, while 56 students completed the third part and 30 students completed the fourth part. When analyzed at the level of 180 respondents, $84 \%$ of them are students at the university study programs (majority of them at the undergraduate level), while the remaining 16\% study in the professional study programs (Graph 1.). 
Graph 1.

\section{DISTRIBUTION OF RESPONDENTS ACCORDING TO THE TYPE OF THEIR STUDY PROGRAM}

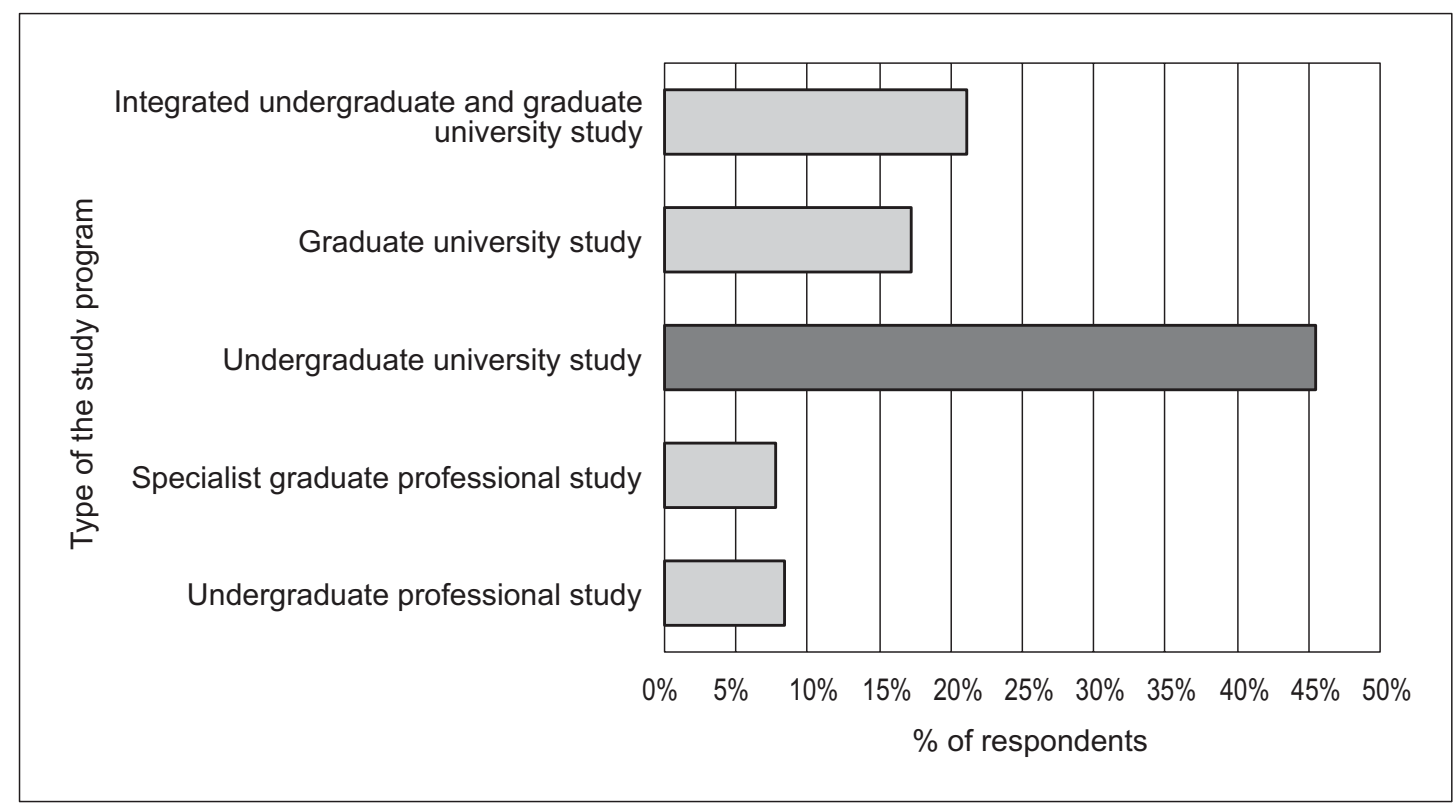

Source: created by the authors.

Attitudes and knowledge of accounting terminology are potentially under the influence of exposure to accounting, either during education or during employment. As far as the experience of respondents in accounting before enrolling in the faculty is concern, the important information is that almost an equal percentage of respondents attended secondary economics school as well as secondary schools that are non-economic orientation (51\% vs. 49\%). Most of the respondents attended three accounting courses during their study (Graph 2.), which primarily depends on their current year of the study. In addition to exposure to accounting terminology during education, $23 \%$ of the respondents also have experience in accounting jobs. On the other hand, $52 \%$ of them have experience in non-accounting jobs, while $25 \%$ have no experience. 
Graph 2.

\section{DISTRIBUTION OF RESPONDENTS ACCORDING TO THE NUMBER OF ACCOUNTING COURSES THEY ATTENDED DURING THE STUDY}

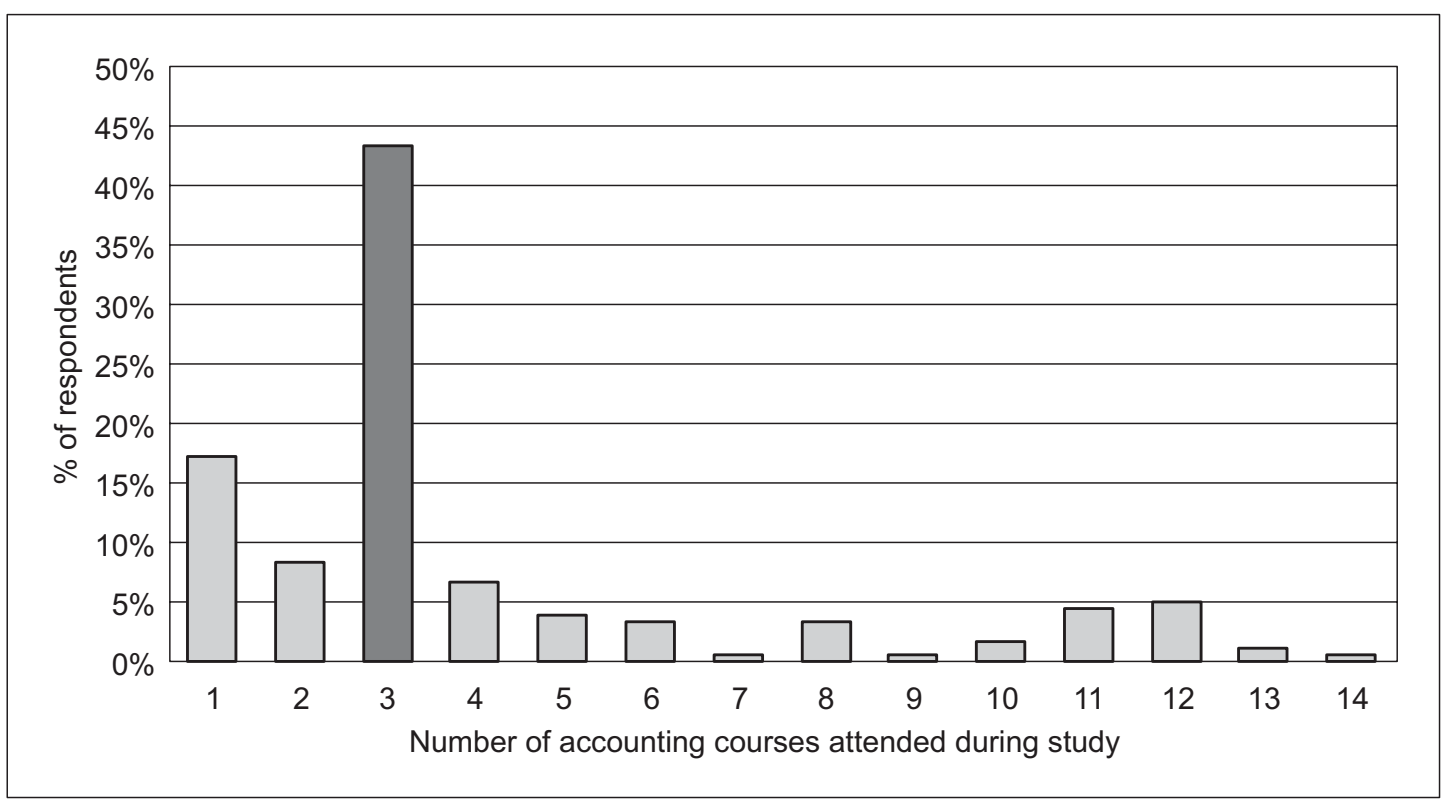

Source: created by the authors.

Respondents were given a list of nine statements related to accounting terminology in Croatia and were required to rate their level of agreement on a 5-point Likert scale ( 1 - completely disagree, 5 - completely agree). Since the ability to assess the last two statements depends on the respondents' previous education, they were also given the option $O$ - cannot assess. These answers were excluded from calculating measures of descriptive statistics (Table 2.), which is why the number of answers (column count) is below 180. According to the calculated measures of central tendency, it is evident that the respondents mostly agree that the accounting courses often use different synonyms for the same concept, which they find unnecessary and confusing. However, based on mode, they are also aware that using multiple synonyms during courses for the same accounting concepts is useful because it serves as a preparation for practice, which is in line with the conclusions drawn from the analysis of accounting courses curricula. Despite their aversion towards synonyms in accounting terminology, respondents mostly disagree that the accounting terminology is too complex and incomprehensible, since the mode and median values are 2 . However, mean value (2.47) is not representative 
due to high variation in grades assigned, which is evident from a $44 \%$ coefficient of variation. The respondents could not agree on certain statements which proved to be debatable, such as the statement that there are differences in the terms used in various accounting courses during the study, where all three measures of central tendency are equal or very close to 3 .

Table 2.

\section{DESCRIPTIVE STATISTICS ON THE GRADES ASSIGNED TO STATEMENTS RELATED TO ACCOUNTING TERMINOLOGY IN CROATIA}

\begin{tabular}{|l|c|c|c|c|c|c|c|}
\hline \multicolumn{1}{|c|}{ Statement } & Count & Sum & Average & $\begin{array}{c}\text { Standard } \\
\text { deviation }\end{array}$ & $\begin{array}{c}\text { Coefficient } \\
\text { of variation }\end{array}$ & Mode & Median \\
\hline $\begin{array}{l}\text { Multiple synonyms of the same } \\
\text { accounting concepts are unnecessary and } \\
\text { confusing }\end{array}$ & 180 & 661 & 3.67 & 1.01 & $27.51 \%$ & 4 & 4 \\
\hline $\begin{array}{l}\text { Accounting courses often use different } \\
\text { synonyms for the same concept }\end{array}$ & 180 & 608 & 3.38 & 0.93 & $27.59 \%$ & 4 & 4 \\
\hline $\begin{array}{l}\text { Using multiple synonyms during courses } \\
\text { for the same accounting concepts is } \\
\text { useful because it serves as a preparation } \\
\text { for practice }\end{array}$ & 180 & 606 & 3.37 & 1.03 & $30.50 \%$ & 4 & 3 \\
\hline $\begin{array}{l}\text { There are differences in the terms used } \\
\text { in various accounting courses during } \\
\text { the study }\end{array}$ & 180 & 545 & 3.03 & 1.00 & $32.92 \%$ & 3 & 3 \\
\hline $\begin{array}{l}\text { In practice, there are no multiple } \\
\text { synonyms for the same accounting } \\
\text { concepts. }\end{array}$ & 180 & 443 & 2.46 & 1.02 & $41.61 \%$ & 3 & 2 \\
\hline $\begin{array}{l}\text { Accounting regulatory in Croatia is fully } \\
\text { aligned regarding the terms used }\end{array}$ & 180 & 537 & 2.98 & 0.90 & $30.08 \%$ & 3 & 3 \\
\hline $\begin{array}{l}\text { Accounting terminology is too complex } \\
\text { and incomprehensible }\end{array}$ & 180 & 445 & 2.47 & 1.09 & $44.19 \%$ & 2 & 2 \\
\hline $\begin{array}{l}\text { Accounting terminology is harmonized } \\
\text { in all institutions of higher education in } \\
\text { Croatia }\end{array}$ & 116 & 368 & 3.17 & 1.11 & $34.94 \%$ & 4 & 3 \\
\hline $\begin{array}{l}\text { Compared to the secondary education, } \\
\text { different terms for certain accounting } \\
\text { concepts are used throughout the study }\end{array}$ & 121 & 332 & 2.74 & 1.11 & $40.45 \%$ & 2 & 3 \\
\hline
\end{tabular}

Source: calculated by the authors. 
M. BROZOVIĆ, S. SEVER MALIŠ, A. NOVAK: The consistency and complexity of accounting terminology in Croatian... EKONOMSKI PREGLED, 70 (3) 496-518 (2019)

Since one of the aims of the research was to explore the attitudes of students about the complexity of accounting terminology, which is the statement with the highest coefficient of variation among all nine statements, an additional analysis was conducted. It is obvious that the respondents are not a homogeneous group regarding their perception on accounting terminology complexity and comprehensibility. Therefore, it was examined if the attitudes of students are under the influence of their characteristics such as education and experience. Descriptive statistic measures are given in Table 3., calculated separately for each group of students based on their characteristics.

Table 3.

DESCRIPTIVE STATISTICS ON THE GRADES ASSIGNED TO THE STATEMENT REGARDING COMPLEXITY OF ACCOUNTING TERMINOLOGY IN CROATIA CALCULATED SEPARATELY FOR EACH GROUP OF STUDENTS

\begin{tabular}{|c|c|c|c|c|c|c|c|c|}
\hline Characteristic & Variable & Count & Sum & Average & $\begin{array}{l}\text { Standard } \\
\text { deviation }\end{array}$ & $\begin{array}{c}\text { Coefficient } \\
\text { of variation }\end{array}$ & Mode & Median \\
\hline \multicolumn{2}{|l|}{ All respondents } & 180 & 445 & 2.47 & 1.09 & $44.19 \%$ & 2 & 2 \\
\hline \multirow{2}{*}{ Study program } & $\begin{array}{c}\text { Professional } \\
\text { study }\end{array}$ & 29 & 70 & 2.41 & 1.12 & $46.22 \%$ & 2 & 2 \\
\hline & $\begin{array}{l}\text { University } \\
\text { study }\end{array}$ & 151 & 375 & 2.48 & 1.09 & $43.93 \%$ & 2 & 2 \\
\hline \multirow{4}{*}{ Year of study } & 2 & 46 & 109 & 2.37 & 1.15 & $48.49 \%$ & 2 & 2 \\
\hline & 3 & 8 & 18 & 2.25 & 0.83 & $36.85 \%$ & 2 & 2 \\
\hline & 4 & 95 & 236 & 2.48 & 1.12 & $45.19 \%$ & 2 & 2 \\
\hline & 5 & 31 & 82 & 2.65 & 0.93 & $35.34 \%$ & 2 & 2 \\
\hline \multirow{3}{*}{$\begin{array}{l}\text { Number of } \\
\text { accounting } \\
\text { courses }\end{array}$} & $1-3$ & 124 & 305 & 2.46 & 1.13 & $46.01 \%$ & 2 & 2 \\
\hline & $4-6$ & 25 & 59 & 2.36 & 1.02 & $43.01 \%$ & 2 & 2 \\
\hline & $>6$ & 31 & 81 & 2.61 & 0.97 & $37.24 \%$ & 2 & 2 \\
\hline \multirow{2}{*}{$\begin{array}{l}\text { Secondary school } \\
\text { type (economy) }\end{array}$} & Yes & 91 & 218 & 2.40 & 1.21 & $50.61 \%$ & 2 & 2 \\
\hline & No & 89 & 227 & 2.55 & 0.95 & $37.18 \%$ & 2 & 2 \\
\hline \multirow{3}{*}{ Experience } & No & 44 & 115 & 2.61 & 1.17 & $44.84 \%$ & 2 & 2 \\
\hline & $\begin{array}{l}\text { Yes, in non- } \\
\text { accounting } \\
\text { jobs }\end{array}$ & 94 & 231 & 2.46 & 1.06 & $43.08 \%$ & 2 & 2 \\
\hline & $\begin{array}{c}\text { Yes, in } \\
\text { accounting } \\
\text { jobs }\end{array}$ & 42 & 99 & 2.36 & 1.07 & $45.18 \%$ & 2 & 2 \\
\hline
\end{tabular}

Source: calculated by the authors. 
When observed at the level of separate groups of respondents, there are certain differences in mean values of grades assigned. It is interesting that some of these differences are contrary to what was initially expected. Students at the university study programs are more critical regarding the complexity and comprehensibility of accounting terminology in Croatia when compared to students at the professional study programs. It is additionally surprising that there is a positive trend in means values of grades assigned as the year of the study and the number of accounting courses increases, meaning that the mean grades are moving away from 2 - mostly disagree towards 3 - neither agree or disagree. Students in the fifth year, which refers to the graduate accounting students, are significantly more critical on the accounting terminology complexity than the students in lower years, which can be attributed to the fact that they attend notably more accounting courses in their final year of the study. On the other hand, it was expected that the students who have experience in accounting jobs or previously attended secondary economic school will mostly disagree with the statement that the accounting terminology is complex and incomprehensible.

In order to analyze if these relationships between assigned grades and respondents' characteristics are statistically significant, a Chi square independence tests were performed. Pairs of variables whose independence was examined are shown in Table 4. The results have proved that all pairs of variables are mutually dependent, since the calculated p-value is lower than the level of significance of $5 \%$. In other words, there is a connection between the assigned grades and study program, year of study, number of accounting courses attended, secondary school type and working experience.

Table 4.

RESULTS OF CHI SQUARE TESTS FOR THE VARIABLES ASSIGNED GRADES FOR THE STATEMENT RELATED TO THE COMPLEXITY OF ACCOUNTING TERMINOLOGY IN CROATIA AND RESPONDENTS' CHARACTERISTICS

\begin{tabular}{|l|c|c|c|}
\hline \multicolumn{1}{|c|}{ Variables analyzed } & $\begin{array}{c}\text { Chi square } \\
\text { statistics }\end{array}$ & $\begin{array}{c}\text { Degrees of } \\
\text { freedom }\end{array}$ & P-value \\
\hline Assigned grade vs. Study program & 175.14 & 4 & $<0.00001$ \\
\hline Assigned grade vs. Year of study & 180.12 & 12 & $<0.00001$ \\
\hline $\begin{array}{l}\text { Assigned grade vs. Number of accounting } \\
\text { courses }\end{array}$ & 196.36 & 52 & $<0.00001$ \\
\hline Assigned grade vs. Secondary school type & 185.98 & 4 & $<0.00001$ \\
\hline Assigned grade vs. Experience & 177.89 & 8 & $<0.00001$ \\
\hline
\end{tabular}

Source: calculated by the authors. 
In addition to rating statements related to accounting terminology in Croatia, 56 students also answered questions in the third part of the questionnaire, where they were required to select a term that they prefer among provided synonyms from accounting terminology. The list of provided synonyms mostly corresponds to the synonyms that were identified during the analysis of accounting courses curricula in higher education institutions. It is evident that the students' preferences regarding using accounting synonyms are under the influence of the terms that are usually used during their accounting courses and are mentioned in the courses curriculum, which means that the similar conclusions apply again. For example, in certain cases students prefer borrowed accounting terms (e.g. cro. inventura over popis, or interne kontrole over unutarnje kontrole), while there are also instances where the native accounting terms dominate (e.g. cro. najam over leasing, nadzor over monitoring, or proračun over budžet). It is interesting that the majority of students prefer term statement of changes in capital over statement of changes in equity, which is the opposite from the occurrence frequencies of these terms in analyzed accounting curricula. The remaining results can be seen form the Table 5. It can be concluded that the students' preferences are also not completely uniform, which may partially be the result of the fact that multiple synonyms are used during teaching accounting courses. 


\section{Table 5.}

\section{STUDENTS' PREFERENCES ABOUT USING SYNONYMS IN ACCOUNTING TERMINOLOGY}

\begin{tabular}{|c|c|c|c|c|c|c|c|}
\hline & Croatian term & English term & $\%$ & & Croatian term & English term & $\%$ \\
\hline \multirow{9}{*}{ 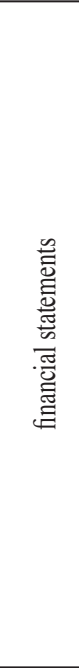 } & financijski izvještaji & financial statements & 91 & \multirow{12}{*}{ 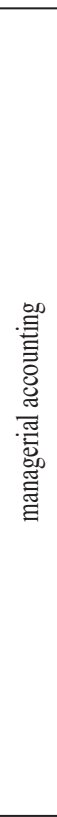 } & $\begin{array}{l}\text { računovodstvo za } \\
\text { poslovođenje }\end{array}$ & $\begin{array}{l}\text { accounting for } \\
\text { management }\end{array}$ & 2 \\
\hline & financijska izvješća & financial reports & 9 & & upravljačko računovodstvo & & 91 \\
\hline & analiza financijskih izvještaja & $\begin{array}{l}\text { analysis of financial } \\
\text { statements }\end{array}$ & 89 & & $\begin{array}{l}\text { menadžersko } \\
\text { računovodstvo }\end{array}$ & managerial accounting & 7 \\
\hline & analiza financijskih izvješća & $\begin{array}{l}\text { analysis of financial } \\
\text { reports }\end{array}$ & 11 & & bruto marža & gross margin & 86 \\
\hline & izvještaj o novčanom toku & cash flow statement & 64 & & doprinos pokrića & coverage contribution & 7 \\
\hline & izvještaj o novčanim tokovima & & 34 & & marginalna kontribucija & marginal contribution & 7 \\
\hline & $\begin{array}{l}\text { izvještaj o novčanim } \\
\text { tijekovima }\end{array}$ & cash flows statement & 2 & & proračun & budget & 73 \\
\hline & $\begin{array}{l}\text { izvještaj o promjenama } \\
\text { kapitala }\end{array}$ & $\begin{array}{l}\text { statement of changes } \\
\text { in capital }\end{array}$ & 71 & & budžet & buaget & 27 \\
\hline & $\begin{array}{l}\text { izvještaj o promjenama } \\
\text { glavnice }\end{array}$ & $\begin{array}{l}\text { statement of changes } \\
\text { in equity }\end{array}$ & 29 & & izravni i neizravni troškovi & \multirow[t]{2}{*}{ direct and indirect costs } & 46 \\
\hline \multirow{7}{*}{ 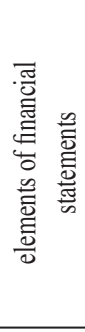 } & financijski rezultat & financial result & 25 & & direktni i indirektni troškovi & & 54 \\
\hline & rezultat poslovanja & result of business & 57 & & točka pokrića & break-even point & 96 \\
\hline & poslovni rezultat & business result & 18 & & prijelomna točka & breakpoint & 4 \\
\hline & revalorizacijske rezerve & \multirow{2}{*}{ revaluation reserves } & 95 & \multirow{14}{*}{ 兽 } & nadzor & & 88 \\
\hline & revalorizacijske pričuve & & 5 & & monitoring & monitoring & 13 \\
\hline & potraživanja za PDV & VAT receivable & 50 & & revizijski odbor & audit committee & 64 \\
\hline & pretporez & pretax & 50 & & revizorski odbor & audit committee & 36 \\
\hline \multirow{7}{*}{ 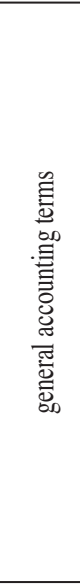 } & leasing & leasing & 23 & & $\begin{array}{l}\text { unutarnje kontrole i } \\
\text { unutarnja revizija } \\
\text { interne kontrole i interna } \\
\text { revizija }\end{array}$ & $\begin{array}{l}\text { internal controls and } \\
\text { internal audit }\end{array}$ & $\begin{array}{l}29 \\
71\end{array}$ \\
\hline & saldakonti dobavljača & 1 & 30 & & revizijski izvještaj & audit statement & 16 \\
\hline & $\begin{array}{l}\text { analitičko knjigovodstvo } \\
\text { obveza }\end{array}$ & $\begin{array}{l}\text { analytical } \\
\text { bookkeeping of } \\
\text { suppliers }\end{array}$ & 70 & & revizijsko izvješce & \multirow[t]{2}{*}{ audit report } & 25 \\
\hline & obračun PDV-a & VAT calculation & 98 & & revizorsko izvješće & & 41 \\
\hline & saldiranje PDV-a & settlement of VAT & 2 & & izvješće neovisnog revizora & $\begin{array}{l}\text { report of independent } \\
\text { auditor }\end{array}$ & 13 \\
\hline & \multirow{2}{*}{$\begin{array}{l}\text { godišnja inventura } \\
\text { godišnji popis }\end{array}$} & \multirow{2}{*}{$\begin{array}{l}\text { annual inventory } \\
\text { annual stocktaking }\end{array}$} & \multirow{5}{*}{$\begin{array}{r}91 \\
9 \\
\end{array}$} & & revizorovo izvješce & auditor's report & 5 \\
\hline & & & & & revizijska društva & \multirow{4}{*}{ audit firm } & 21 \\
\hline & & & & & revizorske tvrtke & & 16 \\
\hline & & & & & revizijske tvrtke & & 9 \\
\hline & & & & & revizorska društva & & 46 \\
\hline
\end{tabular}

Source: calculated by the authors. 
In the fourth part of the questionnaire, students were given a list of eight main terms and were required to identify all appropriate synonyms. Total number of respondents that completed this part of the questionnaire is 30 . The possible answers, as well as the percentage of respondents who marked a particular answer, are presented in Table 6. Respondents were the most familiar with the titles of financial statements. Out of total number of respondents, $83 \%$ of them identified the balance sheet as the synonym for the statement of financial position, while $73 \%$ connected income statement to the profit and loss account. However, certain terms proved to be less known among students. For example, only 16\%/18\% identified the trial balance (represented by two terms in Croatian: pokusna bilanca and probna bilanca) as a synonym for the term gross balance. Similar situation applies for the two terms that are in Croatian used for the chart of accounts (cro. kontni plan and računski plan). The synonyms for the term audit are debatable, which is a common issue across the majority of languages. If the meaning of the term audit is viewed in the narrow sense, then none of the offered terms are appropriate synonyms, because audit is a broader concept and includes all types of audit. However, in a broader sense, the term audit is often associated with the audit of financial statements or external audit, and it is therefore understandable that more than half of the students have chosen these terms. 
Table 6.

\section{SUCCESS OF RESPONDENTS IN RECOGNIZING ACCOUNTING TERMINOLOGY SYNONYMS}

\begin{tabular}{|c|c|c|c|c|c|c|c|}
\hline \multirow{2}{*}{$\begin{array}{c}\text { Main term } \\
\text { - Croatian / } \\
\text { English }\end{array}$} & \multicolumn{2}{|c|}{ Potential synonyms } & \multirow[b]{2}{*}{$\%$} & \multirow{2}{*}{$\begin{array}{c}\text { Main term } \\
\text { - Croatian / } \\
\text { English }\end{array}$} & \multicolumn{2}{|c|}{ Potential synonyms } & \multirow[b]{2}{*}{$\%$} \\
\hline & Croatian term & English term & & & Croatian term & English term & \\
\hline \multirow{8}{*}{$\begin{array}{l}\text { poduzeće / } \\
\text { company }\end{array}$} & gospodarski subjekt & economic entity & 63 & \multirow{7}{*}{$\begin{array}{l}\text { bruto } \\
\text { bilanca } \\
\text { / gross } \\
\text { balance }\end{array}$} & zaključna bilanca & closing balance sheet & 30 \\
\hline & poslovni subjekt & business subject & 97 & & pokusna bilanca & trial balance & 30 \\
\hline & trgovačko društvo & company & 83 & & bilanca & balance sheet & 20 \\
\hline & kompanija & company & 73 & & probna bilanca & trial balance & 33 \\
\hline & dioničko društvo & joint stock company & 50 & & $\begin{array}{l}\text { izvještaj } 0 \\
\text { financijskom položaju }\end{array}$ & $\begin{array}{l}\text { statement of financial } \\
\text { position }\end{array}$ & 20 \\
\hline & tvrtka & firm & 50 & & ništa od navedenoga & none of the above & 23 \\
\hline & ništa od navedenoga & none of the above & 0 & & robno knjigovodstvo & inventory bookkeeping & 40 \\
\hline & račun dobiti i gubitka & profit and loss account & 17 & \multirow{4}{*}{$\begin{array}{l}\text { analitičko } \\
\text { knjigovo- } \\
\text { dstvo } \\
\text { sirovina i } \\
\text { materijala / } \\
\text { analitical } \\
\text { book-eeping } \\
\text { of raw } \\
\text { materials } \\
\text { and } \\
\text { materials }\end{array}$} & $\begin{array}{l}\text { materijalno } \\
\text { knjigovodstvo }\end{array}$ & material bookkeeping & 67 \\
\hline \multirow{3}{*}{$\begin{array}{l}\text { izvještaj } \\
\text { o financi- } \\
\text { jskom } \\
\text { položaju / } \\
\text { statement } \\
\text { of financial } \\
\text { position }\end{array}$} & $\begin{array}{l}\text { izvještaj o novčanim } \\
\text { tokovima }\end{array}$ & cash flows statement & 0 & & $\begin{array}{l}\text { saldakonti kupaca i } \\
\text { dobavljača }\end{array}$ & $\begin{array}{l}\text { customer and supplier } \\
\text { accounts }\end{array}$ & 7 \\
\hline & $\begin{array}{l}\text { izvještaj o promjenama } \\
\text { kapitala }\end{array}$ & $\begin{array}{l}\text { statement of changes } \\
\text { in capital }\end{array}$ & 0 & & $\begin{array}{l}\text { analitičko } \\
\text { knjigovodstvo kupaca } \\
\text { i dobavljača }\end{array}$ & $\begin{array}{l}\text { analytical } \\
\text { bookkeeping of buyers } \\
\text { and suppliers }\end{array}$ & 3 \\
\hline & bilanca & balance sheet & 83 & & $\begin{array}{l}\text { skladišna evidencija } \\
\text { sirovina i materijala }\end{array}$ & $\begin{array}{l}\text { inventory records of } \\
\text { raw materials and } \\
\text { materials }\end{array}$ & 43 \\
\hline \multirow{7}{*}{$\begin{array}{l}\text { račun dobiti } \\
\text { i gubitka / } \\
\text { profit and } \\
\text { loss account }\end{array}$} & pokusna bilanca & trial balance & 17 & \multirow{7}{*}{$\begin{array}{l}\text { računski } \\
\text { plan / chart } \\
\text { of accounts }\end{array}$} & ništa od navedenoga & none of the above & 10 \\
\hline & ništa od navedenoga & none of the above & 7 & & kontni plan & chart of accounts & 50 \\
\hline & $\begin{array}{l}\text { izvještaj o promjenama u } \\
\text { financijskom položaju }\end{array}$ & $\begin{array}{l}\text { statement of changes } \\
\text { in financial position }\end{array}$ & 13 & & plan nabave & purchase plan & 17 \\
\hline & $\begin{array}{l}\text { izvještaj o sveobuhvatnoj } \\
\text { dobiti }\end{array}$ & $\begin{array}{l}\text { statement of } \\
\text { comprehensive income }\end{array}$ & 33 & & $\begin{array}{l}\text { knjiga ulaznih i } \\
\text { izlaznih računa }\end{array}$ & $\begin{array}{l}\text { book of incoming and } \\
\text { outgoing invoices }\end{array}$ & 10 \\
\hline & izvještaj o dobiti & income statement & 73 & & plan prodaje & sales plan & 20 \\
\hline & $\begin{array}{l}\text { izvještaj o financijskom } \\
\text { položaju }\end{array}$ & $\begin{array}{l}\text { statement of financial } \\
\text { position }\end{array}$ & 10 & & financijski plan & financial plan & 27 \\
\hline & $\begin{array}{l}\text { izvještaj o ostaloj } \\
\text { sveobuhvatnoj dobiti }\end{array}$ & $\begin{array}{l}\text { statement of other } \\
\text { comprehensive income }\end{array}$ & 17 & & knjiga blagajne & cashbook & 7 \\
\hline \multirow{8}{*}{$\begin{array}{l}\text { kapital / } \\
\text { capital }\end{array}$} & ništa od navedenoga & none of the above & 10 & \multirow{8}{*}{$\begin{array}{c}\text { revizija / } \\
\text { audit }\end{array}$} & ništa od navedenoga & none of the above & 20 \\
\hline & glavnica & equity & 90 & & interna (unutarnja) & & 40 \\
\hline & vlasnički kapital & owner's capital & 60 & & revizija & mither Iral audut & 40 \\
\hline & vlasnička glavnica & owner's equity & 63 & & $\begin{array}{l}\text { revizija financijskih } \\
\text { izvještaja }\end{array}$ & $\begin{array}{l}\text { audit of financial } \\
\text { statements }\end{array}$ & 57 \\
\hline & temeljni kapital & share capital & 50 & & eksterna revizija & external audit & 53 \\
\hline & zarađeni kapital & earned capital & 20 & & kontroling & controlling & 27 \\
\hline & ništa od navedenoga & none of the above & 0 & & $\begin{array}{l}\text { sustav internih } \\
\text { kontrola }\end{array}$ & internal control system & 20 \\
\hline & & & & & ništa od navedenoga & none of the above & 17 \\
\hline
\end{tabular}

Source: calculated by the authors. 
This part of the questionnaire has proved that the accounting terminology is challenging for a certain number of students. However, their knowledge and attitudes toward the accounting terminology surely depends on their overall study preferences and interests, as well as future perspectives, which is why it is understandable that their interest and knowledge about accounting terminology differs to a certain extent.

\section{Conclusion}

Accounting terminology is a specialized terminology that is a main communication tool among the members of the accounting profession. However, the application of this terminology is much wider. Due to the concepts of corporate governance and financial reporting, even the general public must be familiar with basic accounting terms. Literature review suggests that the accounting terminology may sometimes be perceived as complex or incomprehensible, due to multiple changes and variations of accounting terms. Due to a lack of similar research in the field of higher education, a research was conducted with the aim of analyzing accounting terminology used in the higher education institutions in Croatia.

The first part of the research was conducted on a sample of institutions, whose accounting courses curricula were analyzed to explore the consistency of accounting terminology in higher education. The analysis of differences in used accounting terms led to several conclusions: 1) there is a time lag in the adoption of terms that are imposed on a regulatory basis in order to replace exiting terms, 2) the influence of foreign languages is evident in a form of borrowed accounting terms, and 3) the analyzed courses in most cases are not uniform regarding the terminology used. These results were expected, since the previous research proved that the same applies for the Croatian regulatory accounting framework, which is why using different synonyms for the same accounting concepts may be beneficial for students.

The research was further supplemented by examining the attitudes of students about the complexity of accounting terminology. The students who participated in the research mostly agree that the accounting courses often use different synonyms for the same concept, which they find unnecessary and confusing. However, they are also aware that using multiple synonyms during courses for the same accounting concepts is useful because it serves as a preparation for practice, which is in line with the conclusions drawn from the analysis of accounting courses curricula. On the other hand, they mostly disagree with the statement that the accounting terminology is too complex and incomprehensible, which has proved 
to be influenced by the students' characteristics, such as the type of study program enrolled, year of study, number of accounting courses attended, secondary school type and working experience. In addition, it was shown that the students' preferences regarding using accounting synonyms are under the influence of the terms that are usually used during their accounting courses and are mentioned in the courses curriculum, as well as that they experience certain difficulties in identifying appropriate synonyms for the given accounting terms. The main limitation of the secondary part of the research is the fact that the sample of institutions whose courses were analyzed was intentional and based on the availability of the data on courses content and curricula on institutions' web page. On the other hand, the primary research was conducted among students of one institution, and therefore may only serve as an indicator on students' attitudes towards complexity of accounting terminology, while the generalization is not recommended. Potential opportunities in future research include widening the sample of higher education institutions, in order to increase the representativity of the research, as well as extending the research to the secondary education.

\section{Acknowledgement:}

This work has been fully supported by Croatian Science Foundation under the project "Construction of Croatian Accounting Terminology" (Struna-2017-09-03).

\section{References:}

Blank, A. (1999). Why do new meanings occur?: A cognitive typology of the motivations of lexical semantic change, in: Blank, A. and Koch, P. (eds.). Historical semantics and cognition, Berlin and New York: Mounton de Gruyter, 61-89.

Dickins, D., Daugherty, B., Dee, C. C. and Higgs J. (2016). The terminology of going concern standards: How subtle differences in wording can have a big impact. The CPA Journal, 86(1), online. Available at: https://www.cpajournal.com/2016/01/13/terminology-going-concern-standards/

Evans, L. (2004). Language, translation and the problem of international accounting communication. Accounting, Auditing \& Accountability Journal, 17(2), 210-248. 
Evans, L. (2010). Observations on the changing language of accounting. Accounting History, 15(4), 439-462.

Hrvatski terminološki portal [Croatian Terminology Portal] (2018). Što je nazivlje? [What is terminology?] Institut za hrvatski jezik i jezikoslovlje [Institute for Croatian Language and Linguistics], online. Available at: http://nazivlje. $\mathrm{hr} /$ clanak/sto-je-nazivlje/14/

Kirk, N. E. (2001). "True and fair view" versus "present fairly in conformity with Generally Accepted Accounting Principles". Massey University School of Accountancy Discussion Paper Series, online. Available at: http://www. massey.ac.nz/massey/fms/Colleges/College\%20of\%20Business/School\%20 of\%20Accountancy/Documents/Discussion\%20Papers/208.pdf

Lee, E. and Ling, E. (2016). Confused with terms such as "probable", "reasonably possible" and "possible"? You're not the only one. Australian Accounting Standards Board, Chartered Accountants Australia and New Zealand, online. Available at: https://www.charteredaccountantsanz.com/-/media/4a55e3 49b970453b830d21d16ede97cc.ashx

Mamić Sačer, I., Dečman, N. i Rep, A. (2018). Practical problems in understanding accounting terminology used in the preparation of general purpose financial statements - evidence from Croatia. Proceedings of the 7th International Scientific Symposium Economy of Eastern Croatia - vision and growth, Osijek, Croatia, 1077-1085.

Mamić Sačer, I., Pavić, I. and Žager, L. (2018). Analysis of equality of principal accounting terminology in Croatian normative framework. Proceedings of Researchfora 16th International Conference, Hamburg, Germany, 1520. Available at: http://www.worldresearchlibrary.org/up_proc/pdf/1505152811318415-20.pdf

Norberg, C. and Johansson, J. (2013). LSP Journal - Language for special purposes, professional communication, knowledge management and cognition, 4(1), 30-48.

Porter, B. A. (1996). A research study on financial reporting and auditing - bridging the expectation gap. Accounting Horizons, 10(1), 130-135.

Silhan, P. A. (1978). The recurring problem of divergent terminology. The Accounting Review, 53(1), 179-181.

Sirbu, A. (2015). The significance of language as a tool of communication. "Mircea cel Betran” Naval Academy Scientific Bulletin, 18(2), 405-406.

Stolle. C. D. (1973). An analysis of inconsistencies in the terminology of the opinions of the Accounting Principles Board. Dissertation, Graduate College of Texas A\&M University, USA. Available at: https://search.proquest.com/ docview/302708310?pq-origsite=summon 


\title{
Williams, P. (2005). Accounting: Semantically challenged. Financial Director, online. Available at: https://www.financialdirector.co.uk/2005/10/24/ac- counting-semantically-challenged/
}

\section{UJEDNAČENOST I SLOŽENOST RAČUNOVODSTVENE TERMINOLOGIJE U HRVATSKOM SUSTAVU VISOKOG OBRAZOVANJA}

\author{
Sažetak
}

Najvažnija uloga jezika je obično olakšati komunikaciju, što često predstavlja izazov ako je upotrijebljena terminologija nedosljedna, složena ili nerazumljiva. Takvi problemi mogu posebno biti izraženi u slučaju specifičnog jezika koji je karakterističan za određenu profesiju, pogotovo u slučaju kad se zahtijeva komunikacija s osobama koje ne pripadaju toj profesiji. Sukladno pregledu literature, može se doći do zaključka da se računovodstvena terminologija ponekad smatra složenom ili neshvatljivom, primarno zbog čestih promjena ili varijacija korištenih računovodstvenih termina. Budući da je uočen nedostatak sličnih istraživanja u području visokog obrazovanja, provedeno je istraživanje s ciljem analize računovodstvene terminologije koja se koristi u institucijama višeg i visokog obrazovanja u Hrvatskoj. U analizi su korišteni sekundarni i primarni podaci. Sekundarni podaci obuhvaćali su nastavne planove i programe računovodstvenih kolegija institucija višeg i visokog obrazovanja iz uzorka, koji su analizirani kako bi se istražila ujednačenost korištene računovodstvene terminologije. Osim toga, istraživanje je dopunjeno prikupljanjem primarnih podataka pomoću upitnika o stavovima studenata vezano uz složenost računovodstvene terminologije. Analiza termina korištenih u nastavnim planovima i programima dovela je do zaključka da obuhvaćeni računovodstveni kolegiji u većini slučajeva nisu usklađeni po pitanju računovodstvene terminologije. Međutim, takvi rezultati su očekivani zahvaljujući rezultatima prijašnjih istraživanja, koja su pokazala da isto vrijedi i za regulatorni računovodstveni okvir u Hrvatskoj, zbog čega se može zaključiti da korištenje različitih računovodstvenih sinonima tijekom obrazovanja zapravo može biti korisno za studente. Što se tiče stavova studenata o računovodstvenoj terminologiji, pokazalo se da se studenti koji su sudjelovali u istraživanju uglavnom slažu da računovodstveni kolegiji često koriste različite sinonime za isti pojam. Iako im to djeluje zbunjujuće, svjesni su i da je upotreba višestrukih sinonima tijekom nastave korisna jer služi kao priprema za praksu. S druge strane, uglavnom se ne slažu s tvrdnjom da je računovodstvena terminologija presložena ili nerazumljiva, za što se pokazalo da u određenoj mjeri ovisi o njihovim pojedinačnim obilježjima, kao što su vrsta upisanog studija, godina studija, broj odslušanih računovodstvenih kolegija, vrsta pohađane srednje škole te radno iskustvo. Ovo istraživanje nadopunjuje prethodna istraživanja provedena u Hrvatskoj u drugim područjima gdje je prisutna računovodstvena terminologija, kao što su zakonodavstvo ili poslovna praksa, što je glavni znanstveni doprinos rada. Što se tiče praktičnih implikacija, rezultati istraživanja mogu poslužiti kao indikator osobama u obrazovnom sustavu i regulatorima, budući da je potencijalni problem nedosljednosti i složenosti računovodstvene terminologije u nastavnim planovima i programima direktna posljedica nedosljednosti i složenosti računovodstvene terminologije u računovodstvenoj regulativi.

Ključne riječi: računovodstvena terminologija, institucije višeg i visokog obrazovanja, nastavni planovi i programi računovodstvenih kolegija, usklađenost, sinonimi. 